\title{
BEHAVIOUR SETTING AND SPATIAL USAGE ANALYSIS ON SOMBO LOW COST FLAT'S CORRIDOR
}

\author{
Annisa Nur Ramadhani*, Muhammad Faqih**, Arina Hayati** \\ *) Master Student at Departement of Architecture, Faculty of Architecture, Design \\ and Planning \\ **) Lecturer at Departement of Architecture, Faculty of Architecture, Design and \\ Planning \\ Institut Teknologi Sepuluh Nopember, Surabaya 60111, Indonesia \\ e-mail: annisa.arch@gmail.com
}

\begin{abstract}
Flats corridors' designs that are relatively narrow are less able to accommodate the needs of social space for residents in low cost flats. This is because Indonesian people are used to livinge in horizontal housing, one of them being the kampung. The kampung alley provides for various forms of dynamic activity and social interaction for resident, and make it to be a good social space. Related to this fact, architects have the task of designing flats corridors that could accomodate residents' needs for social space such as the user's behaviour setting in a kampung street. This issue is in line with the case study in Sombo Flat's corridor which was designed based on the characteristics of a kampung street's behaviour setting concept. With that concept, flats corridors were designed very wide, approximately 3-9 meters. This wide corridor give residents the opportunity for social interaction and other dynamic activities that take place in the corridors. This paper aims to evaluate the design implementation of the Sombo Flat's corridors using analysis on behaviour setting method, which covers the pattern of the activities, setting/milieu, synormophy (the relationship between activity and the setting), and also analysing space usage patterns that occur in the corridors. The data are collected through observation, interview, documentation and analyze with descriptive qualitative methods. The results of the research show that Sombo Flat's corridor, designed based on the characteristics of a kampung street concept, can accomodate the resident's pattern of activities well, especially in the function of social space to create a sense of neighborhood. However, the negative impact from this wide corridor design is that it gives residents an opportunity to appropriate their personal space in the corridor which supposedly is a public space (thereby changing the spatial usage).
\end{abstract}

Keywords: Behaviour Setting, Environment Behaviour Study, Flats Corridor's Design, Spatial Usage 


\section{INTRODUCTION}

Space, including outdoor space, is one of the results of architecture and urban design. Space is affected by geography, built environment, social practices, and culture which can direct human behaviour into a certain pattern (Lang 1978). In addition, space is also influenced by the perceptions, experience, spatial behaviour, and the meanings perceived by the user (Stea, 1977 and Hersberger, 1969). Perception of someone coming to a space is also influenced by cultural factors. Culture is formed contextually and has distinctive characteristics relating to an individual in the context of various regions and settings. In line with the above, Altman (1976) has elaborated and formulated a concept of the Environment Behavior Study (EBS), which consists of three components: environment-behavior phenomena, user group, and settings. Altman has emphasized that there is a reciprocal relationship between human behavior and the environment or setting.

The relationship between human behavior and environmental setting will not be separated from the time variable. In this case there is a link between patterns of activity, environmental setting, and the relationship between them within a certain time period commonly called the Behaviour Setting (Barker, 1968). The pattern of human activity in a space can either change by the time period whether per day, per week, or per season. Behaviour setting systems may vary from time to time. Most of them depend on the location and characteristics of the user. Changes in the function of the link into place can also occur, in which a space that was originally in the form of a link, because of certain factors could turn into a place (Lang and Marshall, 2016)

The diversities of this behaviour setting can be seen on the street, where the users can perform various activities and behaviour patterns such as standing, talking, playing, gathering, and observing. Also pertinent is path connectivity including vehicle mobility and pedestrians. All these activities can form an urban life that has a significant impact on the environment and socio-cultural community (Jacob, 1993).

Street as a link in the context of housing in Indonesia has adapted to the each typology of housing. This reflects a dualism in housing typology in Indonesia, that is, horizontal and vertical housing. Kampung is one of the horizontal housing types and it has street or alley to link one house to another. On the other side, flats are one of the vertical housing types, having a corridor to link one house unit to another in the same level.

However, there is an activity pattern difference between Kampung Street and Flats Corridor that will affect the behaviour setting of the user. Most of the people in Indonesia are not familiar with vertical housing culture. Flat's corridors that are relatively narrow and vertical housing settings are less able to accomodate the needs of the user's social space, different from the Kampung street that provides various activity, social interactions, and social space. Related to this fact, architects have the task to design flats corridors that could accomodate residents needs for social space such as user's behaviour setting in a kampung street. This issue is in line with the case study in Sombo Flat's corridor which was designed based on the characteristics of a kampung street's behaviour setting concept. With that concept, 
flats corridors were designed very wide, approximately 3-9 meters. These wide corridors give residents the opportunity for social interaction and other dynamic activities to take place in the corridors. Resident who live in Sombo flats once lived in a slum area in the same location, but were then relocated into these flats (Silas, 1996).

This paper will discuss the behaviour setting analysis in Sombo Flats, to identify whether the corridor's design is good enough or not to accomodate social activities patterns and social space the same as in the Kampung Street.

From the problem statement above, the research questions are:

1. How is the user's behaviour setting pattern in Sombo flat's corridor?

2. What is the use of space pattern in Sombo flats?

3. Can the flat's corridor design accomodate the user's behaviour setting the same as in the Kampung street?

\section{THEORY / RESEARCH METHODS}

\section{Research Methods}

The research method was used descriptive qualitative method. Observations and field survey were performed to analyze patterns of activity that occur in each milieu and how they relate to each other (behavior setting). The descriptive qualitative method is to explain whether the corridor design can accomodate the user's behaviour setting the same as in the Kampung street or not. The techniques of data collection were literature review, observation, photography, and interview with the residents.

\section{Behaviour Setting}

According to Roger Barker in Zeisel (1981), behaviour setting is the codetermination relation between the environment and the behavior pattern that can not be separated from one another. According to Barker, behaviour setting is human behavior in a reciprocal relationship with the environment. Behavior settings can be defined as an interaction between an activity and the setting where it occurs.

Lang (2010) defines the behaviour setting as an attempt to create a built environment to provide the desired activity affordances that can occur in a neighborhood setting; whether appropriate or not depends on the moral and cultural fabric of local communities. which are:

Barker (1968) in Lang (2010) reveals some variables of the behavior setting,

1. There is an activity pattern that is repeated in the form of a behaviour pattern

2. There is a milieu or certain environmental setting

3. Synomorphy or the relationship between patterns of activity and milieu exists

4. There is a specific time period

Meanwhile, Rapoport (2005) has argued a theory system of setting which is similar to behaviour setting that Barker had outlined. However, Rapoport criticized 
the lack of one variables that would have a significant influence on a behavior setting. That variable was a cultural variable. Rapoport suggested four aspects of the system of setting:

1. The organization of space, time, meaning, and communication

2. A system of settings

3. The cultural landscape

4. A combination of fixed, semi-fixed, and non fixed elements

In Popov (2012), Barker (1968) also mentions an additional aspect in the behavior setting aside from the three main aspects mentioned above. The full set are: Temporal locus; Geographical locus; Social occurrence; Duration; Population; Occupancy time; Functional positions of inhabitants; Action patterns; Behavior mechanisms; Pressure; Autonomy; Welfare

Besides the aspects mentioned above by Roger Barker, John Lang (2010) has stated that the built environment is composed of two types of behavior setting, which are:

1. Places are the sites of localized standing patterns of behavior

2. Links are the channels of movement that draws them into a system that serves some purpose or set of purposes

\section{Activity in Behaviour Setting}

There are four aspects of activity in behavior settings, according to Rapoport (in Kent, 1990):

1. Instrumental aspects which are the most manifest

2. How activities are carried out

3. How they are associated into a system

4. Their meaning, the most latent aspect.

In analyzing the behavior setting, there are several key questions related to the relationship between the environment and the pattern of its activities (Rapoport, in Kent 1990):

1. Who does what

2. Where

3. When

4. Including or excluding whom (and why)?

Meanwhile, according to Kent (1990), the system of setting could include the following aspects:

1. The nature of the setting, some of which may be counter intuitive

2. How and by whom settings are used, depending on appropriate meaning

3. Who is included or excluded

4. The penetration gradients

5. The rules that apply in them

6. The on-going user behaviour and activity

7. The cues provided by the setting

8. The nature of boundaries

9. The sequence of settings

10. The reason for particular sequences

11. The extent of the system which, in turn, is related to home ranges, known areas, areas used or avoided

12. The linkages and separation among settings

13. The nature or linkages among barriers 


\section{Space Usage Pattern in Specific Milieu}

Rapoport (1977) named the five basic elements of space usage pattern as consisting of:

1. Home Range

A space used by residents in performing the movement or activity that can consist of multiple locations and the connective tissue between these locations and that are influenced by the characteristics of their communities.

2. Core Area

Among the most frequently used by the public in carrying out its activities and controlled by the community itself.

3. Territory

A space that is owned by a group of people who have similar interests in that space.

4. Controlled Area (jurisdiction)

The space occupied and controlled by the people who use itr for a while, and not permanent.

5. Personal Space

An area that is dominated and controlled by each individual.

Research by Lauria (2014) suggests some aspects of spatial use in the analysis of behavior in the context of setting neighborhoods in the cities of Surabaya, which are as follows:

1. Street usage for the economic space

2. Street usage for the social space

3. Street usage for the cultural space

4. Street usage for the spiritual space

5. Street usage for the parking area

\section{Shared Outdoor Space in the Context of Kampung}

Rolalisasi (2013) mentions that the shared outdoor space in the context of an urban village in Indonesia is an alley or a small street in a kampung. However, this also embraces the other areas around settlements that are used together for the communities' activities and for creating a sense of neighborhood among them. Funo (1985) mentions that the open spaces outside the home have a significant role for the life in the kampung. The kampung street is used for various activities such as cooking, washing, playing, bathing, and community gatherings. To reduce the area of shared outdoor space in the village means to extinguish the culture in the village.

\section{Shared Outdoor Space in the Context of Flats}

In the context of flats, Astuti (2015) reveals the ambiguity for the definition of personal space and public space where, in the context of Indonesia, the flat's 
corridor which is supposed to be public space is used as a personal space by users. This is because users need additional space to perform everyday activities. This condition eventually leads to conflicts among users, which in turn have an impact on sustainable housing and the perceived satisfaction of each user (Astuti, 2015).

\section{RESULTS AND DISCUSSION}

\section{Users' Activity (Spatial Pattern)}

Historically, Sombo flats are the result of urban renewal and relocation of people living in slums in the same location previously. This caused the expectation that activities patterns that occur in the flats should accommodate the social activities as in the kampung, but of course there are differences that will be affected by the environmental setting, where flats are vertical space and the kampung is horizontal space.

Activities patterns in the flats were certainly almost equal to the users' activities in the kampung, such as the primary activities which were done almost every day such as eating, bathing, washing, drying clothes, and cooking. Also included was the need for secondary activities such as socializing, playing, trading, and so forth. Analysis obtained in the field observations shows some key activities that are occuring in the flats corridor, as follows:

Table 1. Key Activity that Occurs in Flat's Corridors

\begin{tabular}{|c|c|c|c|c|c|c|}
\hline No & $\begin{array}{l}\text { Activity Pattern } \\
\text { in Sombo Flats }\end{array}$ & $\underset{\mathbf{n}}{\mathrm{Me}}$ & Woman & Youths & Childrens & Outsiders \\
\hline 1 & Bathing & $\checkmark$ & $\checkmark$ & $\checkmark$ & $\checkmark$ & \\
\hline 2 & Cooking & & $\checkmark$ & & & \\
\hline 3 & Washing & & $\checkmark$ & & & \\
\hline 4 & Drying Clothes & & $\checkmark$ & & & \\
\hline 5 & Playing & & & $\checkmark$ & $\checkmark$ & \\
\hline 6 & Socializing & $\checkmark$ & $\checkmark$ & $\checkmark$ & $\checkmark$ & \\
\hline 7 & $\begin{array}{l}\text { Trading or Other } \\
\text { Economic } \\
\text { Activities }\end{array}$ & $\checkmark$ & $\checkmark$ & & & $\checkmark$ \\
\hline 8 & Certain Events & $\checkmark$ & $\checkmark$ & $\checkmark$ & $\checkmark$ & $\checkmark$ \\
\hline
\end{tabular}

Source: writer survey (2017)

\section{Location Setting}

Because of the similarity of cultural background pattern, the activity pattern that occurs in Sombo Flats and Kampung Sombo tend to be similar. The difference is in 
the milieu or place setting. According to Rolalisasi (2013), the shared outdoor space in the context of a kampung in Indonesia is an alley or a small street, also the other areas around settlements that are used together for the activities of communities to create a sense of neighborhood. Kampung streets tend to accommodate social activities such as socializing, playing, trade and mobility functions for vehicles.

In low cost flats, Astuti (2015) reveals the ambiguity between the functions of personal space and public space where, in the context of Indonesia, the corridors of flats which are supposed to be public space are used as a personal space by the user, because of the user's need foradditional space to perform everyday activities.

\section{Space Usage Patterns}

The space usage patterns in Sombo flats that can be seen in figure 1.

1. Personal Space (green)

Area that is dominated and controlled by each individual. In the case of Sombo flats this is the house unit owned by each resident, where the activities conducted in the personal space were sleeping and eating. Other activities were carried out in public and semi-public space.

2. Home Range (yellow)

Area that is used by residents in performing movement or activity that can consist of multiple locations and connective tissue between these locations. This area is influenced by the characteristics of their communities. In the context of Sombo flats it is the corridor (yellow) which consisting of horizontal and vertical circulation

3. Core Area (light blue color)

The areas that are the most frequently used by the user in carrying out activities and controlled by the community itself. In the context of Sombo Flats these are the light blue area that used by people to socialize, play and do other things in addition to their activity in the personal space.

4. Territory (dark blue)

A space that is owned by a group of people who have similar interests to that space. This area is located at the points of shared space for activities such as cooking, bathing, washing, and drying clothes together in the flats.

5. Controlled Area/ Jurisdiction (red)

The spaces that are occupied and controlled by the people who use them for a while and not permanently. In the context of Sombo flats this is a red area which is used by a street vendor selling in the corridor. The trader is present temporarily, and is followed by the residents activities such as socializing, eating, and playing around the street vendor (figure 1) 


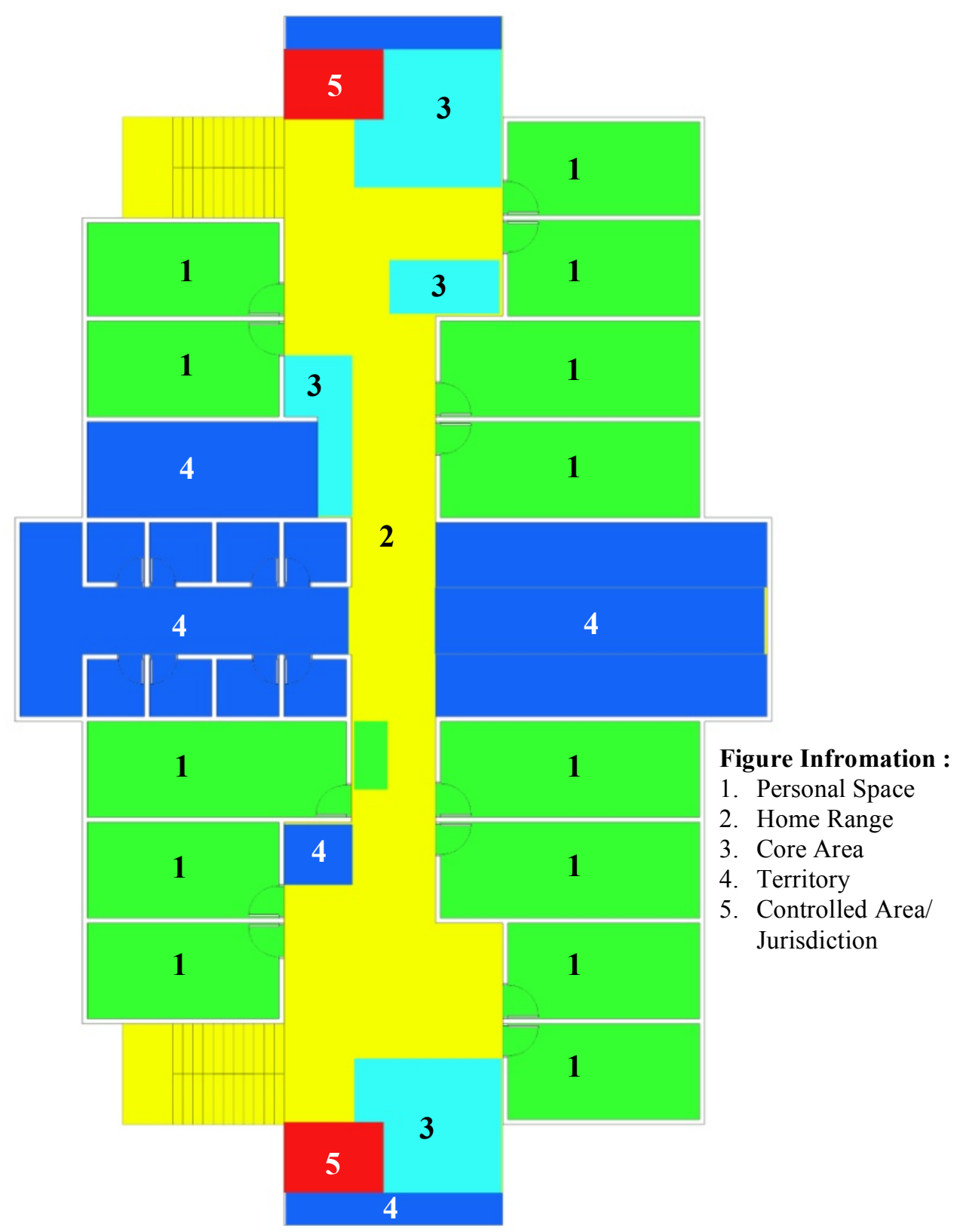

Figure 1. Space Usage Patterns in Sombo Flat Source: survey, 2017 
The space usage pattern will be reviewed further in the corridor setting. The corridor space usage pattern should be a home range area of human movement as a circulation space that connects one place to another. But in reality, flats corridors turns out to have a variety of additional functions. Figure 2 represents a space usage analysis of the corridor:

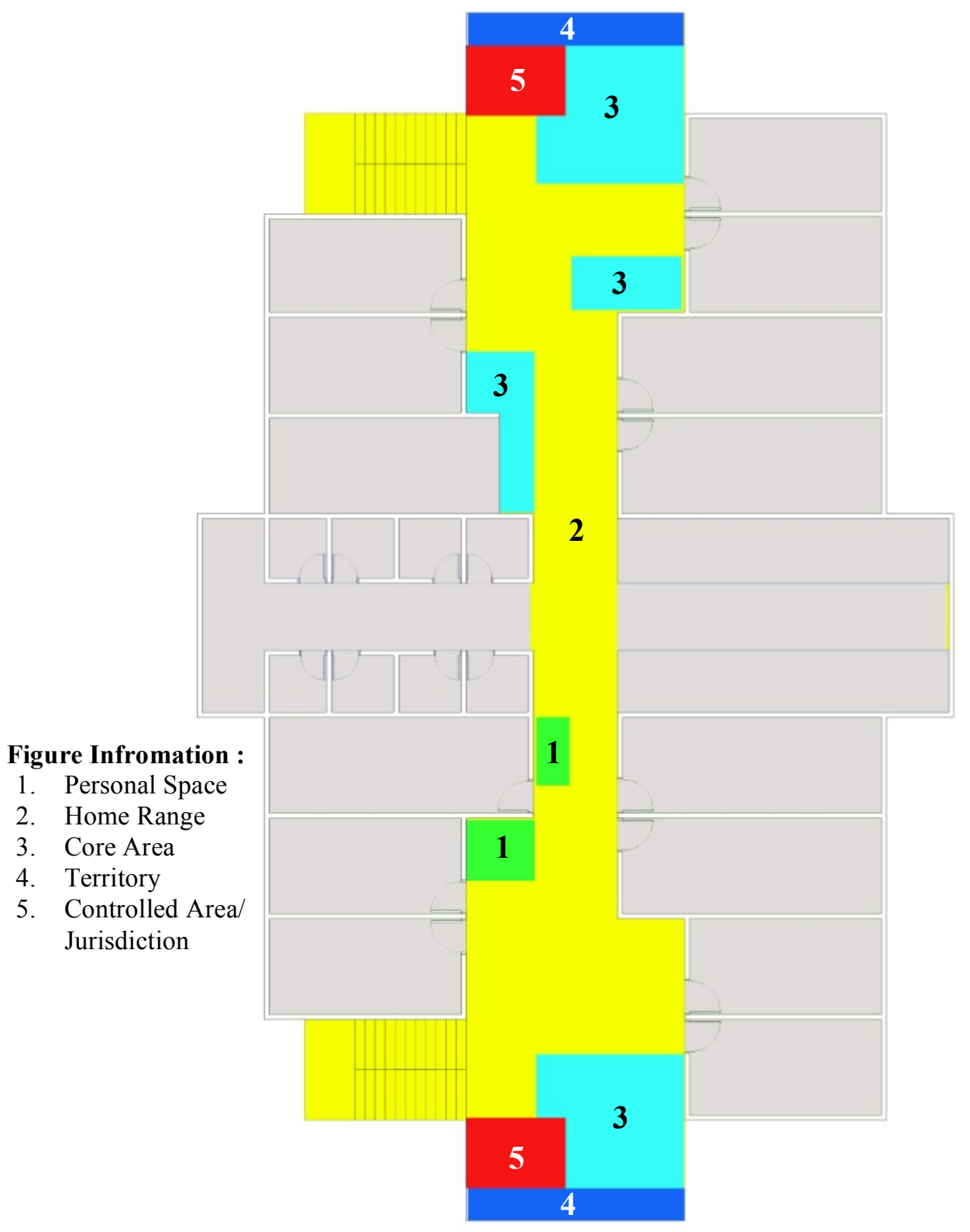

Figure 2. Space Usage Patterns in Sombo Flat's Corridors Source: survey, 2017 


\section{Home Range (yellow)}

A space that is used by residents in performing movement or other activity and which may comprise several locations. Home range is the area of the corridor's low cost flat as a linkage between one place and another, either vertically or horizontally (figure 3).

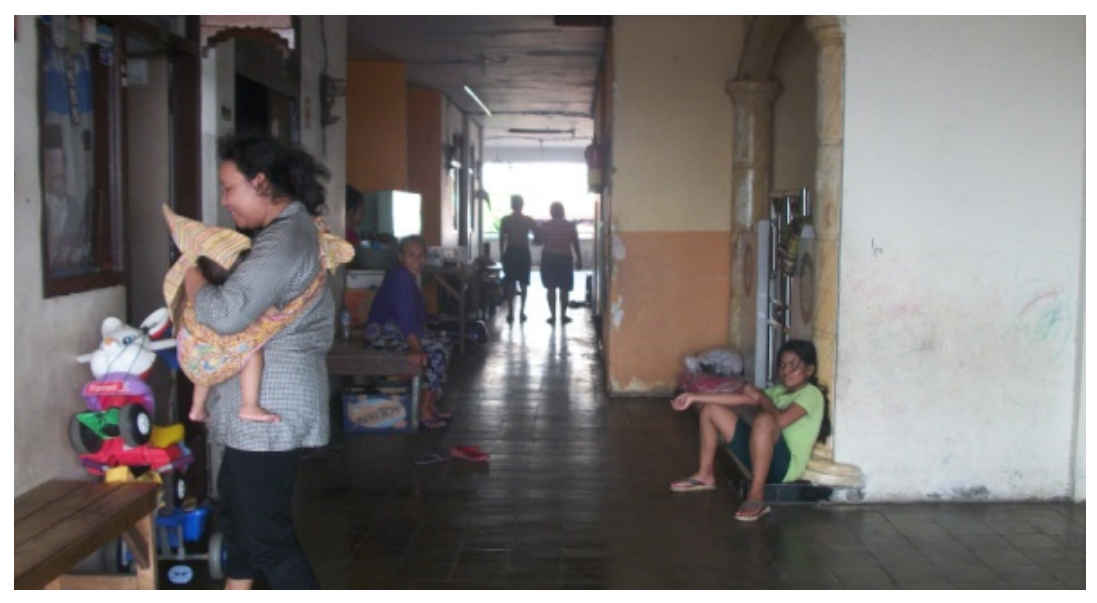

Figure 3. Corridors as a home range

Source: survey, 2017

\section{Personal Space (green)}

In terms of space usage patterns in Sombo flats corridors, there are additional function of personal space in the corridor area which supposedly is to be a public space. Expansion of the personal space areas into the corridor such as privately owned shops is a form of private economic activity. Besides that, there are people who do a sewing business in the corridor. Another expansion form is the cooking activity taking place in front of the house corridor. These are the residents' response to address a perceived lack of personal space (figure 4)
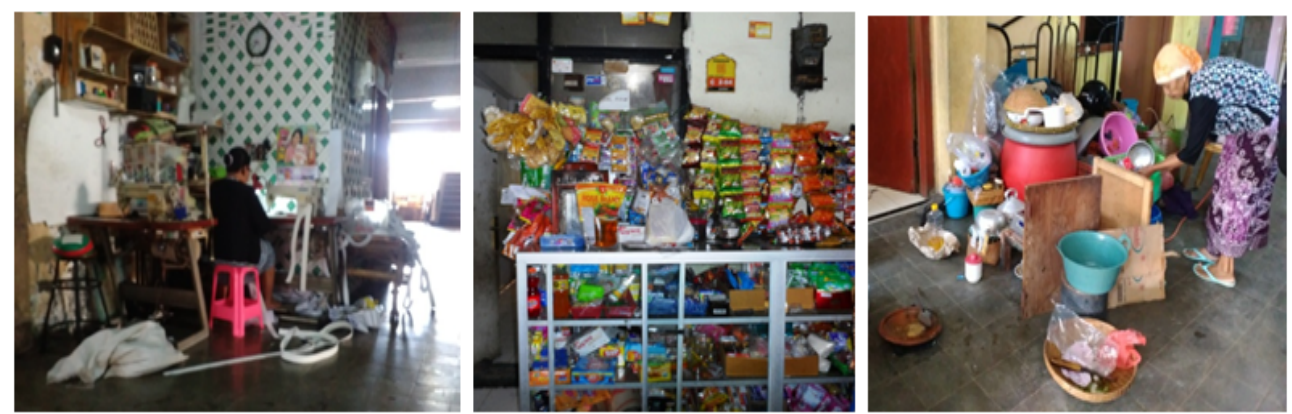

Figure 4. Corridors as a personal space for residents

Source: survey, 2017 


\section{Core Area (light blue color)}

Core area is the most frequently used by the community in carrying out its activities and controlled by the community itself. In the context of Sombo flats, core areas are indicated in light blue color and used by people to socialize, play and relax. It is located in the corner corridor hall that directly faces to the outdoors area. In addition, there are a several benches or seating area that function as core area for social activity among residents. The benches are placed in front of residents' houses (figure 5).
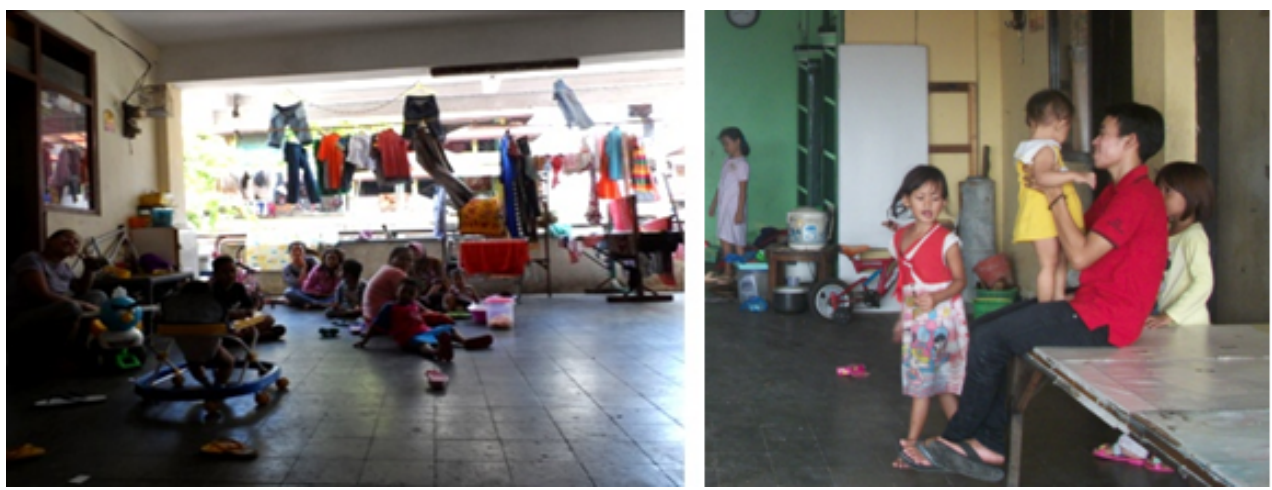

Figure 5. Corridors and seating area as a core area for community Source: survey, 2017

\section{Territory (dark blue)}

A space that is owned by a group of people who have similar interests in that space. This area is located at the end of the corridor where people always use it as an area for communal drying clothes (figure 6).

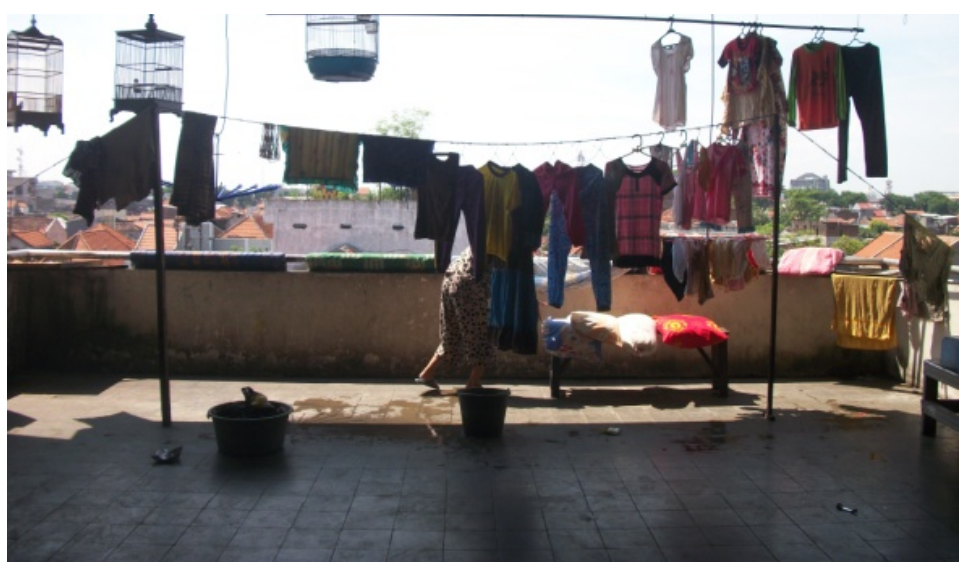

Figure 6. Corridors as territory area for drying clothes

Source: survey, 2017 


\section{Controlled Area / Jurisdiction (red)}

The spaces occupied and controlled by the people who use them for a while and not permanently. In the context of the Sombo flat's corridor, this is a red area which is used as a street vendor selling space. These street vendors are temporary, and are followed by the residents' activities such as socializing, eating, and playing around the street vendors. The interesting thing is that the traders are not people living in these flats, but people from outside the flats who come temporarily (figure 7).
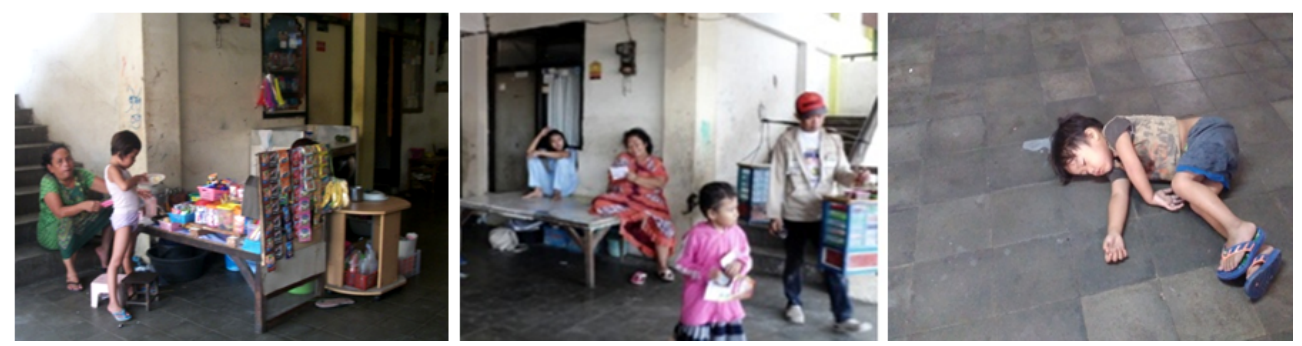

Figure 7. Corridors as a controlled area for temporary street vendors

Source: survey, 2017

Besides that, it is interersting that at night the hall is also used for sleeping by the residents. This is due to the over capacity of housing units that should be occupied by just 4-6 people, but in reality are used by up to 10 people.

\section{Relations between the Behaviour Setting and Time Occurred on Corridor Rusunawa Sombo}

In behavior settings, the time period of the activity is one of the most influencing aspects (Roger Barker 1968). In relation to the Sombo flats corridor, there are differences in activity patterns that occur in a setting from time to time.

Figure 8 shows results from observations of activity pattern changes that occur in the Sombo flat corridor. These changes were observed in the morning, afternoon, and evening. Some of the major activities such as cooking, child care, socializing, play, and even napping in the corridor can be seen in the figure.

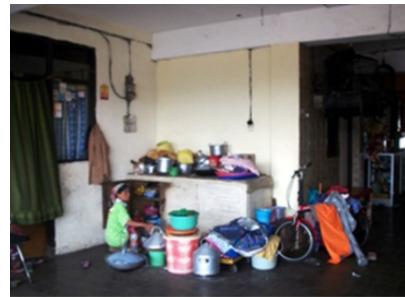

$9 \mathrm{AM}$

Cooking activity take place in corridors in the morning

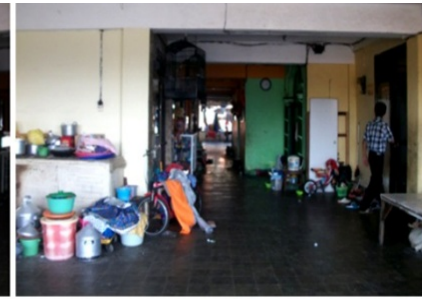

1 PM

In the afternoon, corridors become a link and circulation for residents

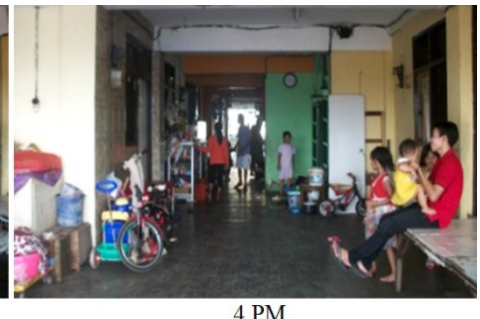

In the evening, corridors become a social space for community

Figure 10. Behaviour Setting in Sombo Flat's Corriodor Source: survey, 2012 


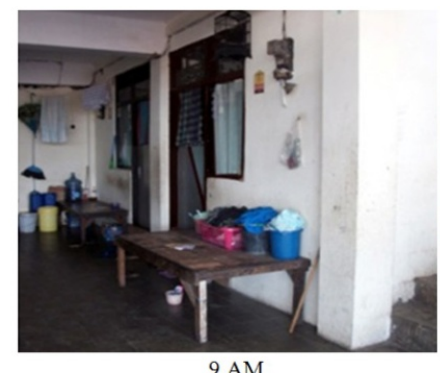

The bench in the morning

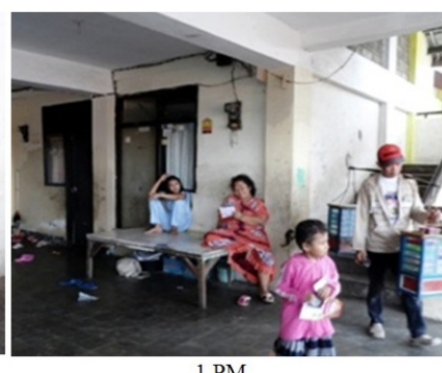

The bench in the afternoon used by the residents for socializing and buying street residents for relaxing and socializing vendors that passed by

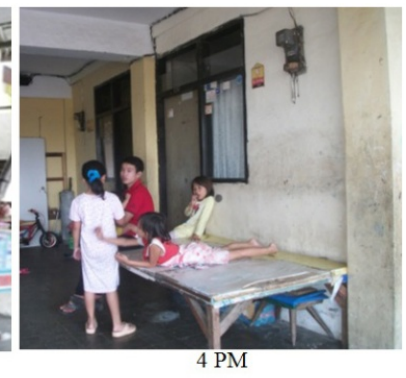

The bench in the evening used by the

Figure 11. Behaviour Setting in Sombo Flat's Corriodor Source: survey, 2012

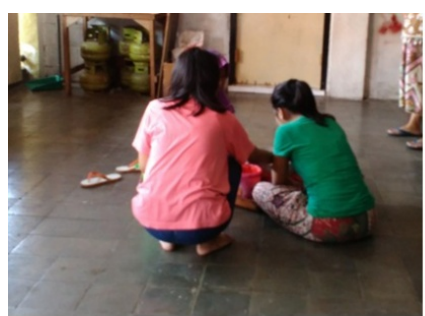

9 AM

Cooking and woman gathering activity take place in corridors in the morning

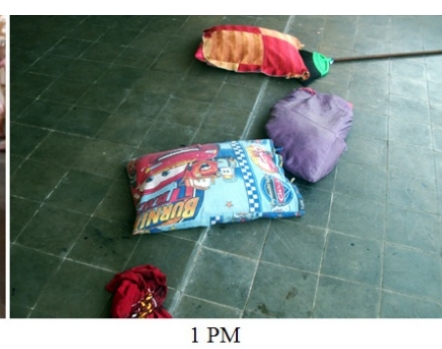

In the afternoon, corridors become a space for children care and nap

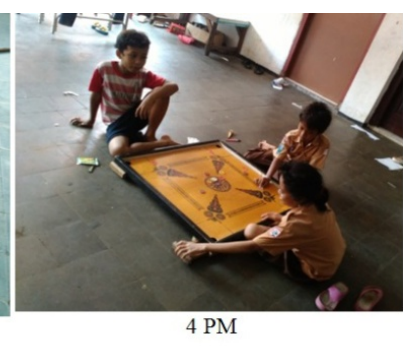

In the evening, corridors become a childern space for playing

Figure 12. Behaviour Setting in Sombo Flat's Corriodor

Source: survey, 2012

\section{CONCLUSION}

Sombo's flats corridor design was based on the character of the kampung's behaviour setting and has been quite successful in its implementation as the embodiment of an appropriate social space. The flats' corridor can serve several activities such as being an economic space where people engage in economic activities such as selling in a grocery store, sewing, even street vendors who go temporarily into the flat's corridor. In terms of its function as a social space, the activity of residents can be accommodated well, ranging from socialization and interaction among residents, the activities of children playing, childcare, to buying food or snacks from street vendors. The spatial usage of the flat's corridor can be categorized into five types, which are corridors as home range for movement activities or lingkage from one place to another; corridors as a personal space for cooking, selling, and even sewing activities of residents performing private activities in the corridors; corridors as a core area for seating and socializing among the residents; corridors as a territory area for drying clothes; and corridors as a controlled area for temporary street vendors and several resident's sleeping in the night.

However, there are also indications of negative impacts from this wide flat's corridors design (3m-9m): specifically it gives residents an opportunity to add to 
their personal space in the corridor which supposedly is intended as a public space (that is, changing spatial usage). Also, because of the wide corriddor, the effective floor area for private house units will be very small (with a bathroom and kitchen that are shared). Because of this, many people use the corridor as an extra room for their personal space, even though the function of the corridor is a public space with shared ownership. There is the ambiguity of private-public space that is happening in the corridor of Sombo's Flats. However, with good communication, agreement, and a high level sense of neighborhood among residents, this is not a big problem for the social cohesion among residents in Sombo flats.

\section{ACKNOWLEDGMENT}

Thanks to God's blessing and grace, so I can finish this research. Thanks are also devoted to Housing and Human Settlements Laboratory Architecture ITS's lecturers for all the knowledge and guidance, so that this research can be completed properly.

\section{REFERENCES}

Altman, Irwin, 1980, Culture and Environment, Wadsworth, Inc, California Astari, Dahlia. 2015, "Pola Pemanfaatan Ruang Pada Selamatan Desa di Permukiman Perkotaan Studi Kasus: Selamatan Desa RW IV Kelurahan Jajar Tunggal Surabaya", Langkau Betang: Vol. 2, No.1 (ISSN 23552484)

Barker, Roger G, 1968, Ecological Psychology: Concepts and Methods for Studying the Environment of Human Behaviour, Stanford University Press, California

Funo, Shuji,. 1985, "Dominant Issues of Three typical Kampungs in Surabaya and Consideration on Kampung Housing System, Studies of Transitional Process of Kampungs and Evaluation of KIP”, Proc. Symposium Peran Perbaikan Kampung Dalam Pembangunan Kota di Indonesia, Indonesia

Lang, Jon, 1987, Creating Architectural Theory, The Role of the Behavioral Sciences in Environmental Design, van Nostrand Reinhold Company

Marcuss, Clare Cooper., 2003, "Shared Outdoor Space and Community Life", Places, 15(2), p. 32-41. Carmel Valley, CA: United States National Institute for Play

Oktay, 2009. Neighborhood satisfaction, sense of community, and attachment: Initial findings from Famagusta quality of urban life study

Rolalisasi, A., Santosa, H., Soemarno, I., 2013, "Social Capital of Urban Settlement", Journal of Psychology and Behavioral Sciences 2(3), p. 83-88

Silas, Johan,. 1988, The Kampungs of Surabaya, Surabaya Municipality, Surabaya

Astuti, S.B., 2015. Personalization as Sustainable Satisfaction, A Comparative Study On Vertical and Horizontal Housing. International Journal of Education and Research: Vol. 3 No. 5 May 2015

Syafrini, Reny, 2010. Evaluation of public openspace performance through the environmental perception and behavior setting in manado. University Politehnica Timisoara, Faculty of Engineering Hunedoara. Romania. 